\title{
Risk-shifting, equity risk, and the distress puzzle
}

\author{
Keming Li ${ }^{\mathrm{a}, 1}$, Jimmy Lockwood ${ }^{\mathrm{b}, 2}$, Hong Miao, ${ }^{\mathrm{b}, *}$ \\ ${ }^{a}$ College of Business, Texas A\&M University-San Antonio, One University Way, San Antonio, TX, 78224, USA \\ ${ }^{b}$ College of Business, Colorado State University, 1272 Campus Delivery, Fort Collins, CO, 80523, USA \\ *Corresponding author. Tel.: 19704912356
}

Email addresses: keming_li@hotmail.com (K. Li), jimmy.lockwood@colostate.edu (J. Lockwood), hong.miao@colostate.edu (H. Miao)

${ }^{1}$ Tel.: +1 2817482971 .

${ }^{2}$ Tel.: +1970672 2117 . 


\title{
Risk-shifting, Equity Risk, and the Distress Puzzle
}

\begin{abstract}
Higher default probabilities are associated with lower future stock returns. The anomaly cannot be explained by strategic shareholder actions, traditional risk factors, characteristics, or mispricing, but, instead, is consistent with a risk-shifting hypothesis. Consistent with the risk-shifting hypothesis, we find that distressed firms tend to overinvest, destroy value, and exhaust their cash flows. Effects are concentrated in firms with wide credit spreads, firms with no convertible debt, and in cases where CEOs receive above-average equity-based compensation. As default risk rises, credit spreads rise, equity betas fall, and equity returns fall.
\end{abstract}

JEL classification: G02; G11; G33

Keywords: Financial Distress; Bankruptcy; Risk-Shifting; Credit Spreads. 


\section{Introduction}

Financial distress risk is commonly cited as an underlying cause of several stock return anomalies. In a rational market, investors should demand higher premiums for holding stocks with higher distress risk. However, studies show returns are lower for firms with high distress risk (Griffin and Lemmon (2002) and Campbell et al. (2008)). Behavioral explanations of the "distress risk puzzle" focus on market mispricing — investors underestimate the implications of high distress risk, and, consequently, fail to demand appropriate risk premiums.

In contrast, the distress risk anomaly might be explained by more complex mechanisms related to the agency theory of debt. In particular, Jensen and Meckling's (1976) offer a risk-shifting hypothesis in which managers of financially distressed firms maximize the limited liability option of shareholders by accepting excessive risk, whereby distressed firms invest in risk-increasing projects offering improbable high pay-offs at the expense of bondholders. Distressed firms generally have abnormally large leverage ratios and proportions of equity that are small relative to their capital structure. Shareholders are likely to lose as high interest payments detract from cash flows. Even trivial shocks to a firm's cash flows may result in default. In these situations, shareholders have little to lose, and, therefore, prefer management to accept risky projects. When these projects are successful, shareholders repay the bondholders and retain the surplus. Conversely, when these projects fail, shareholder downside risks are limited to their stake in the firm upon bankruptcy. As a result, risky projects undertaken by distressed firms lead to a transfer of risk from shareholders to bondholders.

Prior literature related to risk-shifting behavior predominately focuses on the mechanisms that may reduce agency conflicts from a theoretical standpoint. ${ }^{1}$ There is very little empirical evidence whether the problem actually exists. Gilje (2016) finds that firms reduce investment risk as they approach financial distress, disputing the risk-shifting hypothesis. Diamond (1989) and Hirshleifer and Thakor (1992)

\footnotetext{
${ }^{1}$ Theoretical work related to the risk shifting hypothesis includes: Smith and Warner (1979), Barnea et al. (1980, 1981), Green (1984), and John and John (1993).
} 
suggest that managers may avoid risk shifting behavior due to reputational concerns. Similarly, Almeida et al. (2012) suggest risk-shifting behavior could be trumped by concerns regarding the ability to fund future projects. Hernández-Lagos et al. (2016) conduct experiments that provide evidence of both riskshifting behavior and reputational concerns. These studies add to our understanding of risk-shifting behavior - but offer conflicting evidence. We add to the literature by investigating the relationship between risk-shifting behavior and distress risk.

Previous studies relate risk-shifting behavior with liquidation costs. Specifically, risk-shifting behavior is more likely when shareholder advantages and bargaining powers inflate liquidation costs for distressed firms. Alderson and Betker (1996) provide direct estimates of liquidation costs for a sample of bankrupt firms and study their association with a number of commonly used proxies. They conclude that fixed assets, market-to-book ratio, and $R \& D$ expenses are the best variables to use to proxy for liquidation costs. Similarly, Garlappi et al. (2008) and Garlappi and Yan (2011) contend that strategic actions by shareholders during distressed firm debt renegotiation might explain the distress puzzle. In particular, Garlappi et al. (2008) argue default probabilities for distressed firms do not adequately capture equity risks associated with default, especially for firms with strong shareholder advantage. The authors define shareholder advantage as shareholder' capacities to take advantage of other claimholders. Shareholder advantage is proxied by asset size, $R \& D$ intensity, and liquidation cost, and is expected to be high for large firms with lower R\&D costs and higher liquidation costs (proxied by asset specificity variables such as the Herfindahl industry concentration index and the Berger et al. (1996) asset tangibility measure). Garlappi et al. (2008) show that shareholders actions can reduce the effective leverage of equity such that, when default probability is high, equity risk and expected returns are lower for firms with greater shareholder advantage.

In their study of risk-shifting behavior, Davydenko and Strebulaev (2007) examine shareholder bargaining powers. Bargaining power is higher for more obscure firms that are not followed by credit rating agencies, do not have convertible debt, and firms in which the CEO holds equity. Notably, the 
authors show standard proxies for risk-shifting behavior explain very little of the cross-sectional variation of corporate bond prices.

We find distress risk is a robust and negative predictor of future stock returns even after controlling for the effects of strategic shareholder actions. The negative relation is not concentrated in the post-1980s period, is not sample specific, and is not due to different proxies for distress risk. The relation is less likely caused by mispricing issues, as event-time analyses show persistent underperformance patterns and lower equity returns for high default risk firms. Our analysis demonstrates that the distress effect cannot be explained by strategic shareholder actions, traditional risk factors, stock characteristics, or mispricing.

Our results are consistent with a risk-shifting hypothesis. Three major findings support this claim. First, high default firms overinvest, earn low profits, and exhaust their cash flow. These effects are concentrated in low-growth-opportunity firms and in hard-to-value firms. Second, distress effects are concentrated in firms without a credit rating or convertible debt and in firms where CEOs hold equity, all of which are consistent with effects of strategic actions of shareholders. Third, high distress firms tend to exhibit higher credit spreads, lower equity betas, and lower stock returns, even after controlling for stock and bond characteristics and shareholder strategic action effects.

\section{Data and estimation}

We use Center for Research in Securities Prices (CRSP) daily and monthly stock files and COMPUSTAT quarterly and annual research files of firms listed on NYSE, AMEX, and NASDAQ. Unless otherwise noted, the sample period ranges from January 1971 to December 2014. As noted in Campbell et al. (2008), bankruptcies were extremely infrequent until the late 1960s. We eliminate financial and utility companies, as these firms have restricted capital structures. Many studies remove stocks with prices of less than $\$ 5$ to reduce market microstructure issues, but low-priced stocks tend to have much higher default probabilities. Therefore, to reduce effects of liquidity and other market microstructure complications yet maintain otherwise legitimate high risk observations, we only exclude stocks with prices less than $\$ 1$. To be included in the analysis, firms are required to have at least 36 
monthly observations. We conduct our analysis with quarterly accounting data from COMPUSTAT and monthly stock market data from CRSP.

We use corporate bond yield data for July 2002 to December 2014 drawn from the TRACE (Trade Reporting and Compliance Engine) database. These data include FINRA over-the-counter (OTC) corporate bond market real-time prices, as well as details on all eligible corporate bonds including investment grade, high yield, and convertible debt. TRACE represents 100\% of OTC activity and over 99\% of total U.S. corporate bond market activity. We also use ExecuComp data on executive stock and option holdings and on CEO characteristics.

\subsection{Default probability}

We use the default probability measure presented in Campbell et al. (2008). Following their methods, we combine quarterly accounting data from COMPUSTAT with monthly stock market data from CRSP by lagging two months in the accounting data. We estimate time-varying distress probabilities $(D P)$ using the Campbell et al. (2008) "best" model:

$$
D P_{i, t}=P_{i, t}\left(Y_{i, t}=1\right)=\frac{1}{1+\exp \left(-z_{i, t}\right)}
$$

where

$$
\begin{gathered}
z_{i, t}=-9.08-29.67 \text { NIMTAAVG }_{i, t}+3.36 \text { LLMTA }_{i, t}-7.35 \text { EXRETAVG }_{i, t}++1.48 \text { SIGMA }_{i, t} \\
+0.082 \text { RSIZE }_{i, t}-2.40 \text { CASHMTA }_{i, t}+0.054 M B_{i, t}-0.937 \text { PRICE }_{i, t} \\
\text { NIMTAAVG }_{i, t}=\frac{1-\Phi^{3}}{1-\Phi^{12}}\left(\text { NIMTA }_{i, q 1}+\ldots+\Phi^{9} \text { NIMTA }_{i, q 4}\right) \\
\text { EXRETAVG }_{i, t}=\frac{1-\Phi}{1-\Phi^{12}}\left(\operatorname{EXRET}_{i, m 1}+\ldots+\Phi^{11} \text { EXRET }_{i, m 12}\right)
\end{gathered}
$$

where $\Phi=2^{-1 / 3}$. The weights are constant in each quarter for NIMTAAVG and in each month for EXRETAVG. EXRET equals $\ln (1+$ stock return $)$ minus $\ln (1+$ market return $)$. The proxy for the 
market is the value-weighted market index maintained by CRSP. When the lagged EXRET is missing, we substitute the cross-sectional average. NIMTA equals net income divided by the market value of total assets (market value of equity plus book value of liabilities). If the market value is missing, we use the product of prices per share and shares outstanding from the last month of CRSP data from the quarter in lieu of the total market value. TLMTA equals total liabilities divided by market value of total assets. SIGMA is the standard deviation of daily returns over last three months. RSIZE is the relative size measured as the log ratio of firm market capitalization to that of the market. CASHMTA is calculated as cash and short term investments, divided by market value of total assets. Finally, PRICE equals the log price per share. ${ }^{2}$

There are two advantages to using the dynamic logit (hazard model) rather than the option-pricing based model. First, the hazard model utilizes observable and readily available accounting or market data. The relatively low-cost and easily accessible data can be accurately implemented without delays or complications. Second, the hazard model does not rely on an assumptions of the absence of arbitrage opportunities and market frictions. In reality, arbitrage opportunities exist and market frictions are prominent. When basic assumptions are violated, noise is introduced into default risk measures estimated from option pricing models, such as the market-based expected default frequency. ${ }^{3}$ Incremental benefits of using the hazard model are described in in Campbell et al. (2008), who find higher pseudo- $R^{2}$ statistics for their best model both in-sample and out-of-sample in the hazard model vis-a-vis the option pricingbased model.

Table 1 presents mean values of default probability and historical events associated with abnormal upsurges in average default probability by year. For the 44 -year sample period, 31 years show an average

\footnotetext{
${ }^{2}$ Following Campbell et al. (2008), we winsorize price per share at $\$ 15$ before taking logarithms because exploratory analysis indicates prices are relevant below $\$ 15$. This truncation is not applied when calculating stock returns.

${ }^{3}$ Dichev (1998) shows that both the Altman Z-score and Ohlson $O$-score offer high levels of predictive power for out-of-sample bankruptcy.
} 
default probability over $0.1 \%$, and the majority of the spikes are related to financial crises. Average default probability values are much higher during the two most recent crises. The average default probability of the dot-com bubble in 2001 is $1.80 \%$ and that of the 2008 U.S. financial crisis is $6.63 \%$. In contrast, the average default probability of the secondary banking crisis in 1976 is $0.03 \%$ and that of the 1981 Latin American debt crisis is $0.05 \%{ }^{4}$

\subsection{Time-varying betas}

We employ two approaches to estimate time-varying betas, which are updated monthly. First, we use the time-varying beta methodology presented in Lewellen and Nagel (2006). We use rolling regressions of daily returns from the CRSP daily stock file using a standard market model $r_{i t}=\alpha_{i}+\beta_{i} r_{m t}+\varepsilon_{i t}$, with rolling windows of 12 months. The use of a 12-month window is advantageous in that sufficient observations are available for each regression. ${ }^{5}$ This increases the precision of coefficient estimations without compromising the benefits of using a time-varying beta, allowing us to generate equity risk estimates based on pre-formation data.

Second, we use a version of Avramov and Chordia's (2006) conditional model. Ferguson and Shockley (2003) show estimates of beta using an equity-only proxy for the market portfolio can lead to a downward bias. To correct these errors, equity beta estimates should incorporate firm-specific variables that correlate with relative distress or relative leverage patterns. Further, Avramov and Chordia (2006) show that relative to traditional betas, conditional betas are better able to capture explain the variation in cross-sectional returns. Along these lines, Zhang (2005) relates equity beta to firm characteristics such as the book-to-market ratio. Motivated by these findings, we employ a time-varying rolling regression of daily returns in the following model:

\footnotetext{
${ }^{4}$ Default probability in our paper is slightly lower than that shown in Campbell et al. (2008), as we eliminate lower priced stocks and financial firms.

${ }^{5}$ We require at least 50 daily observations over the 12 -month estimation period.
} 


$$
r_{i t}-r_{f t}=\alpha_{i}+\beta_{i, m}\left(r_{m t}-r_{f t}\right)+\beta_{i, B M} B M_{i, t-1}\left(r_{m t}-r_{f t}\right)+\varepsilon_{i t}
$$

where $r_{i t}$ is the daily stock return, $r_{f t}$ is the daily return on the 30-day Treasury bill, $\alpha_{i}$ is the intercept, $\beta_{i, m}$ is the unconditional beta relative to market excess returns, and the conditional beta equals $\beta_{i, m}+$ $\beta_{i, B M} B M_{i, t-1}$.

\section{|Please insert Table 1|}

\subsection{Summary statistics}

Table 2 provides summary statistics of firm-level characteristics, stock returns, and equity betas. The sample includes approximately 1 million firm-month observations with complete data. The data span the period January 1971 - December 2014. Panel A presents the distribution of firm characteristics. Panel B reports averages for firm characteristics by default probability quintile. Panel $\mathrm{C}$ reports means for stock returns and equity risk (equity beta) by default probability quintile. ${ }^{6}$

|Please insert Table 2|

For each month, observations are sorted by default probability levels into quintiles. Time-series averages of the cross-sectional means are presented for each variable. Size is the natural log of market capitalization in millions (at end of year $t-1$ ). $B M$ is the book-to-market ratio, which is calculated as the book value of stockholder equity at year $t$ - 1 divided by the market value of stockholder equity at the end of year $t-1$. These variables are matched with monthly returns from July of year $t$ to June of year $t+1$. $M O M$ is stock momentum, defined as stock returns over the prior year ranging from -12 months to -2 months. All variables are calculated following Daniel et al. (1997). Illiquidity denotes Amihud's (2002) illiquidity measure for the past 12 months of daily trading. Leverage denotes total liabilities over total assets. For each month, we match monthly return data from CRSP data to the firm's quarterly 2-month

\footnotetext{
${ }^{6}$ In the multivariate tests and those that follow, we repeated our analysis using the Naïve Distance to Default measure proposed by Bharath and Shumway (2008) to construct the portfolio rankings. The correlation of the portfolio rankings with the procedure employed in this paper is 0.70 . Thus, it is no surprise that we find the results to be qualitatively similar to those presented in this study. For specific results, please see our online appendix.
} 
lagged default probability. We measure future returns as $t+1$ month returns following portfolio formation. For delisted observations, we follow Shumway and Warther (1999) by replacing the delisted return with the prior month's returns or with the median of delisting returns.

As shown in Panel A of Table 2, the average default probability is $1.055 \%$ and the median is $0.002 \%$. The positive skewness in the default probability distribution is confirmed in Panel B. Only the highest default quintiles show an average default probability of over one percent. $B M$ is positively and related to default probability, which is especially noteworthy given the widespread use of $B M$ as a proxy for distress risk. Results also indicate that default risk is negatively related to momentum, positively related to leverage (consistent with George and Hwang (2010)), and positively related to illiquidity (consistent with Garlappi and Yan (2011)).

Panel C of Table 2 presents results for returns and equity risk by default quintile. Results are derived for excess returns (stock return minus the risk-free rate), Daniel et al. (1997) and Wermers (2004) characteristic-adjusted returns, and Fama and French (1993), Carhart (1997), and Fama and French (2015) multi-factor alphas. ${ }^{7}$ All returns show a general downward trend across the default quintiles, consistent with the distress risk puzzle. Annualized long-short strategies for default quintiles 1 and 5 equal $8.02 \%$ and $3.70 \%$ for excess returns and characteristic-adjusted returns, respectively. And, analogous long-short alphas equal $9.76 \%, 6.92 \%$, and 7.72\%, for the 3-factor, 4-factor, and 5-factor alphas, respectively. The bottom two rows report time-varying betas. Our results show that betas decline across default quintiles. Overall, these results are consistent with a risk shifting hypothesis in which equity risk and equity returns are negatively related to distress risk. We discuss these results in greater detail when discussing the riskshifting proposition.

\footnotetext{
${ }^{7}$ The matching procedure is based on cutoffs of size, the book-to-market ratio, and momentum characteristics drawn from Professor Russ Wermer's web page: http://alex2.umd.edu/wermers/ftpsite/Dgtw/coverpage.htm. The data for the characteristics tests in our paper span the period June 1975 - December 2012.
} 


\section{Empirical Tests}

\subsection{Firm fundamentals and distress risk}

According to the risk-shifting proposition, managers of distressed firms tend to accept risky projects at a cost to bondholders. Shareholders benefit if the investments are successful, and bondholders bear the cost if investments fail. Existing literature suggests conditions under which risk-shifting is likely to occur - for firms with greater growth opportunities (Eisdorfer (2008)) and for hard-to-value firms (Ang et al. (2006)). To investigate the effects of growth opportunities and valuation difficulties, we examine investment intensity, profitability, and cash flow fundamentals of companies in high and low default risk quintiles, segmented by market-to-book ratio $(M B)$ and by idiosyncratic risk $(I R) . M B$ proxies for growth opportunities. Eisdorfer (2008) contends that growth opportunities pose agency conflicts between shareholders and bondholders, and, therefore, firms with greater growth opportunities are more likely to exhibit risk-shifting behavior. $I R$ proxies for valuation uncertainty. Ang et al. (2006) contend that hard-tovalue firms can hide their risk-shifting behavior, thereby avoiding high debt-issuance costs. In contrast, transparent firms are likely to be constrained by debt covenants or regulations that mitigate agency problems related to debt. Hard-to-value firms and firms with high growth opportunities tend to be characterized by high levels of $I R$ and $M B$, respectively.

Table 3 reports time-series averages for investment intensity, profitability, and cash flow intensity separately for low and high default quintiles. Investment intensity is defined as capital expenditure divided by total assets. Firm profitability is measured by $R O E$ (net income divided by shareholder equity), and, as before, Cash Flow is operating cash flow divided by total assets. For each year, observations are sorted into quintiles based on default probability from the previous year (Panel A), and further subdivided by $M B$ and $I R$ (Panels B and C, respectively).

\section{|Please insert Table 3|}

In Panel A, results show that the default probability is positively associated with investment intensity and is negatively associated with profitability and cash flow. Average investment intensity equals $6.3 \%$ 
for low default risk firms and $7.1 \%$ for high default risk firms. ${ }^{8}$ The difference is statistically significant at the 0.01 level. The average $R O E$ for low default risk firms is $15.7 \%$ and that of the high default risk firms is $-17.4 \%$. The difference is $-33.0 \%$, significant at the 0.01 level. This supports the risk-shifting hypothesis principle that managers of high default risk firms engage in value-destroying or negative NPV investment decisions. The difference in cash flow levels provides additional evidence of risk-shifting behavior. The average cash flow level of the low default quintile is positive at $27.6 \%$ and that of the high default quintile is $9.1 \%$. The difference is $-18.5 \%$, significant at the 0.01 level.

Panel B presents the results of risk-shifting behaviors controlling for $M B$. Results show investment intensity is nearly identical for high and low default firms, after controlling for $M B$. The results are consistent with the Eisdorfer's (2008) real options hypothesis that investment decisions depend on growth opportunities. When growth opportunities are similar between low and high default firms, investment intensity also is similar. In contrast, investment intensity is significantly greater for high $M B$ firms versus low $M B$ firms for both low and high default firms (differences of $-2.8 \%$ in both cases).

For high-growth opportunity firms, the distinction between high and low default risk firms should be based on the quality of investments and on marginal resources used for investing. According to the riskshifting hypothesis, high default risk companies invest in all projects, including negative NPV projects, resulting in lower average return on investments. Consistent with the risk-shifting hypothesis, Panel B of Table 3 shows, on average, high $M B$ low default risk firms earn an $R O E$ of $19.4 \%$, and high $M B$ high default risk firms earn $-47.2 \%$. While the difference in ROEs between low and high default firms for the low $M B$ group is negative, the difference is much smaller than the high $M B$ group: $-19.7 \%$ versus $-66.6 \%$, respectively. Results also show that cash flow intensity is significantly less for high default firms and the difference is slightly more exaggerated for high $M B$ firms (-14.6\% for low $M B$ firms versus $-18.6 \%$ for high $M B$ firms).

\footnotetext{
${ }^{8}$ For simplicity, we refer to firms in the low (high) default risk quintile as low (high) default risk firms.
} 
Table 3, Panel C presents the results conditioned on default risk and $I R$. Relative to low $I R$ firms, high $I R$ firms earn lower ROEs (differences of $-9.7 \%$ for low default firms and $-50.1 \%$ for high default firms), but maintain larger cash flow (differences of $9.9 \%$ for low default risk firms and 3.0\% for high default risk firms). Differences in ROEs between low and high default firms are much larger for high $I R$ firms (-16\% for low $I R$ firms versus $-50.4 \%$ for high $I R$ firms), highlighting the relevance of firm profitability relative to firm transparency especially for distressed firms. Interestingly, $R O E$ is positive for high default firms with low IR. These results offer evidence that risk-shifting behaviors and agency problems are mitigated in more transparent firms.

Overall, the results indicate that managers of high default firms tend to overinvest, destroy value, and exhaust their cash flow. Consistent with the risk-shifting proposition, differences in ROEs are more pronounced for firms with high $M B$ and $I R$. Therefore, high default firms with greater growth prospects and hard-to-value firms are more likely to be characterized by risk-shifting behavior. ${ }^{9}$ Figure 1 presents the 5-year moving average of the Investment Intensity, ROE, and Cash Flow for the Low and High Default Portfolios over time. The figure highlights the persistence of risk-shifting behavior over time.

\subsection{Cross-sectional tests controlling for shareholder actions}

We design tests to measure the effects of distress risk after controlling for multi-factor model risks and proxies for shareholder actions. We conduct Fama-MacBeth cross-sectional tests with shareholder strategic action proxies including TANGIBILITY, MBTA, and CURRENT, as recommended and derived by Davydenko and Strebulaev (2007) in their study of the strategic actions of borrowers and lenders. TANGIBILITY is defined as one minus the ratio of net property, plant and equipment divided by book value of total assets. MBTA is the sum of the book value of debt plus the market value of equity divided by the book value of total assets. CURRENT is the ratio of current-to-total debt. ${ }^{10}$ To alleviate skewness

\footnotetext{
${ }^{9}$ We also conducted Table 3 tests after adjusting industry-adjusting all data. No substantive differences were obtained from the industry-adjusted results. For specific results please see our online appendix.

${ }^{10}$ Other strategic action proxies are excluded for data availability reasons or because they are likely to have similar indications as those presented in the risk-shifting hypothesis. For example, the shareholder advantage hypothesis
} 
problems in default probability levels, we use the distress quintile $(D R)$ as a proxy for distress risk which takes a value ranging from one (when a firm occupies the lowest default quintile) through five (when a firm occupies the highest default quintile). To control for peripheral effects, we include the following firm characteristics: Size, BM, MOM for tests conducted on equity returns and Cash Flow, Cash, Sales Growth, $R \& D$, and DY for tests conducted on equity risk. As defined earlier, Cash Flow equals operating cash flow divided by total assets. Cash denotes cash and short-term investments divided by total assets. Sales growth is the average percent change in sales over the prior three years. $R \& D$ denotes research and development expenditures divided by total assets. $D Y$ denotes the dividend yield, equal to most recent year dividends per share divided by the end-of-month share price.

Results of the monthly Fama-MacBeth regressions are reported in Table 4. In Panel A, the dependent variable consists of individual stock excess returns (stock return minus the 1-month Treasury bill return), and in Panel B, the dependent variable consists of the individual stock time-varying betas. For each dependent variable, we report the results of five specifications: (1) $D R$; (2) $D R$ and controls; (3) $D R$, TANGIBILITY, and controls; (4) DR, MBTA, and controls; and (5) DR, CURRENT, and controls. NeweyWest adjusted standard errors are used for all $t$-tests. These specifications are designed to determine whether distress effects have incremental explanatory power after controlling for the effects of stock characteristics and shareholder strategic actions. ${ }^{11}$

\section{|Please insert Table 4|}

Consistent with the prior literature, we find a significant relation between distress risk and subsequent return. Distress risk is a significant and negative predictor of returns - monthly excess returns change 18.4

argues that the fraction of equity owned by a firm's CEO represents equity bargaining power, while the risk-shifting hypothesis interprets the fraction as the degree of alliance between managers and shareholders.

${ }^{11}$ We replicated our analysis using the Ohlsen (1980) "best model" $O$-score. Results are similar to those reported in Table 4. For the full model specification, the $D R$ slope is negative and significant for the tests on equity returns and equity risk. The $D R$ slope estimates equal $-0.167(t$-statistic $=-6.22)$ for the equity returns test and -0.024 ( $t$-statistic $=-3.30)$ for the equity risk test. For specific results see our online appendix. 
basis points for every 1-unit change in default quintile classification. Therefore, on average, stocks in the lowest default quintile earn 73.6 basis points per month or $9.2 \%$ annually, more than stocks in the highest default quintile. Alternative specifications confirm similar results after controlling for firm characteristics and strategic action proxies. These results show that the distress risk anomaly remains after controlling for size, book-to-market, and momentum characteristics, as well as proxies designed to capture the effects of shareholder actions.

Panel B reports results of the equity risk regressions. The default risk coefficient is significant and negative in all regressions, indicating that higher distress risk is associated with lower equity risk before and after purging effects of the control variables. ${ }^{12}$ The results offer strong support for a risk-shifting hypothesis.

\subsection{Time trends in equity beta}

Favara et al. (2012) contend that equity risk falls as the likelihood of strategic default rises. The prospect of favorable debt renegotiations leads to higher expected proceeds for shareholders, and, in the process, equity risk becomes less affected by the uncertainty of the firm's cash flow. To test this hypothesis, we estimate the following cross-sectional regression for stocks in the highest default risk quintile:

$$
\text { Beta }_{i}=\alpha+\beta_{1} \text { Cash Flow }_{i}+\beta_{2}^{\prime} \text { Controls }_{i}+\varepsilon_{i}
$$

where Beta is a time-varying or conditional beta discussed earlier. Controls is a vector of control variables consisting of Cash, Sales Growth, $R \& D$, and Dividend Yields. $\beta_{2}^{\prime}$ is a row vector of coefficients

${ }^{12}$ George and Hwang (2010) and Chava and Purnanandam (2010) show that the negative relation between default risk and future returns is concentrated in periods following 1980. To address the possibility of a time period bias, we conduct subperiod tests: January 1971 - December 1980 and January 1981 - December 2014. For tests on equity returns, slopes on $D R$ are significant in both subperiods, but are lower in the earlier period, $-0.140, t$-statistic $=-2.23$, versus $-0.194, t$-statistic $=-4.28$. For tests on equity risk, the $D R$ slope is significant only in the post- 1980 period, -0.44 , $t$-statistic $=-8.69$ (versus $0.103, t$-statistic $=0.98$ for the earlier period). For specific results see our online appendix . 
for the control variables. The regression is repeated every month, producing monthly estimates of the coefficients.

The estimated coefficients for all months produce a time series of equity risk sensitivities, $\beta_{1}$, to cash flow in the highest distress portfolio. Time trends are estimated by regressing each estimated coefficient in equation (6) on a time trend variable and four lags (McLean (2011)). The lags control for autocorrelation in each coefficient. The time variable ranges from 1 in January of 1971 through 528 in December of 2014. The strategic action hypothesis implies that there is a negative and significant time trend in the cash flow coefficient.

\section{$\mid$ Please insert Table 5|}

Results are reported in Table 5. The Cash Flow coefficient trend is positive and statistically significant, indicating that the average sensitivity of equity risk to Cash Flow increases during the sample period. The time parameter is equal to 0.09 basis points with a $t$-statistic of 3.16 . The Durbin-Watson statistic cannot detect any serial correlation after four lags. Overall, these findings fail to support the hypothesis of strategic shareholder action on equity return or for equity risk. The results are robust with respect to alternative equity risk measures, such as CAPM betas or Fama and French three-factor betas estimated using a rolling window from months $t-60$ through $t-1$.

\subsection{The effect of real options}

The option to accept, reject, or postpone new projects and to change or end current projects is valuable, and may be particularly relevant for the risk-shifting hypothesis. Managers may take advantage of difficulties of determining real option values and may shift equity risks to bondholders. Patterned after Da et al. (2012), we run the following regressions on stock returns and time-varying equity betas, respectively:

$$
\begin{gathered}
\operatorname{Ret}_{i}=a^{\prime} O P_{i}^{d m}+\operatorname{Ret}_{i}^{O A} \\
\operatorname{beta}_{i}=b^{\prime} O P_{i}^{d m}+\operatorname{beta}_{i}^{O A}
\end{gathered}
$$


where Ret denotes excess future $t+1$ month returns, beta is the stock's equity beta in month $t+1, O P^{d m}$ is the vector of cross-sectionally demeaned real option proxies $B M, I R$ (idiosyncratic risk relative to the CAPM), asset growth (the year-over-year percent change in total assets), and $R O A$ (net income relative to the firm's total assets). $\operatorname{Ret}^{O A}$ and beta $^{O A}$ are residuals that purge the effects of real options from $\operatorname{Ret}$ and beta, respectively.

Results of the real options test are similar to those presented in Table 4. For instance, for the test on equity returns, the $D R$ coefficient in the full model specification (bottom set of results in each Panel of Table 4) equals-0.195 ( $t$-statistic $=-7.91)$, which matches closely with -0.181 reported in Panel A of Table 4. Also, for the test on equity betas, the $D R$ coefficient equals -0.025 ( $t$-statistic $=-15.62)$, which is identical to the result reported in Panel B Table 4. Therefore, negative relations between equity returns and equity risks are maintained after considering the effects of real options.

\subsection{The effect of illiquidity}

We address the concern that default risk may serve as a proxy of illiquidity, whereby lower returns in high default risk stocks may be caused by price corrections. To address illiquidity concerns, we conduct an event-time analysis. For each month, we form five value-weighted portfolios based on default probability, and track each portfolio's performance over a subsequent 12-month period. Abnormal returns are derived relative to the Fama-French-Carhart 4-factor model. All factor loadings are estimated by regressing monthly excess returns on Fama and French $(1992,1996)$ and Carhart (1997) momentum factors using the prior five-years of monthly returns with a minimum of 36 months. Abnormal returns are calculated as the return net of post-formation predicted returns using updated factors for each month. Results are illustrated in Figure 2.

If our earlier results of a negative relation between equity returns and distress risk are caused by price convergence of high default risk firms to fundamental value, then long-term default portfolio performance should converge. However, Figure 2 shows that low default risk firms consistently perform better than high default risk firms over 12 months after portfolio formation. Therefore, our results are robust to the possibility that our default risk measure is merely a proxy for illiquidity. 
|Please insert Figure 2|

\subsection{Risk-shifting incentives}

To further analyze whether the distress puzzle is attributed to risk-shifting behaviors, we test distress risk effects in different samples based on risk-shifting incentives or constraints. We examine conditions under which effects of distress risk on equity returns (or equity risk) are likely to be more pronounced. According to the risk-shifting hypothesis, in their attempts to maximize shareholder value, managers may pursue actions harmful to creditors, especially when firms are in distress. The agency costs associated with debt may be affected by various incentives or constraints. Specifically, we examine the effects of coverage by a credit rating agency, the existence of convertible debt in the firm's capital structure, and the existence of equity-based compensation to CEOs. We address each incentive below.

If low equity returns in high distress firms are caused by risk-shifting behavior, distress effects should be weaker in firms covered by credit agencies. To obtain a credit rating, a firm must submit to the scrutiny of rating agencies, which verify the firm's ability to meet its financial obligations. Healy and Palepu (2001) argue that information intermediaries such as rating agencies serve as outside monitors, restricting managerial misconduct, and reducing agency problems for stakeholders.

The existence of convertible bonds in the firm's capital structure helps align management incentives more closely with bondholders, thereby reducing risk-shifting incentives. In his research of investment risk incentives, Green (1984) develops a model emphasizing the role of convertible debt for firms attempting to maximize the value of the residual claim of shareholders. In his model, Green (1984) proves that convertible bond contracts are particularly suitable for controlling risk incentive problems. Because convertible bonds are exchangeable into equity, the risk-shifting hypothesis predicts actions benefitting shareholders at the expense of bondholders will be reduced for firms with convertible debt (also see Barnea et al. (1980) and Ozerturk (2002)). Data on convertible debt are available through the COMPUSTAT annual file.

Brander and Poitevin (1992) and Ertugrul and Hegde (2008) find that managerial compensation structures can affect risk-shifting behavior. In particular, equity-based compensation aligns interests of 
managers and shareholders and intensifies risk-shifting behavior. We test this conjecture using CEO equity holding data (the value of executive stock and option holdings) obtained from COMPUSTATCapital IQ Execucomp Annual Compensation. ${ }^{13}$ Execucomp contains data on companies from the S\&P 1500 Plus.

We repeat the Fama-MacBeth regressions for the full model specification from Table 4 with the addition of dummy variables designed to measure the effects of the three risk-shifting incentives. For simplicity, we report just the results for the slope coefficients on $D R$ and the $D R$ interaction term. The three tests are conducted separately. Results are reported for the slopes on $D R$ and for the interaction terms of $D R$ multiplied by each dummy variable: $C R=1$ if the firm is covered by a credit rating agency, $C B=1$ if the firm's capital structure includes convertible debt, $C E O=1$ if the CEO's equity holdings exceed the sample mean.

\section{|Please insert Table 6|}

Results are reported in Table 6. For stocks in default risk quintile 5, the effect of the binary credit rating variable equals $0.035 \%$ (e.g., $5 \times 0.007 \%$ ) per month or $0.42 \%$ annually. The effects of the remaining risk shifting incentives are more meaningful. For instance, for firms in the high default quintile, equity returns are higher by $0.085 \%$ per month, or $1.02 \%$ annually, for firms with convertible debt, and are lower by $0.26 \%$ per month, or $3.23 \%$ annually for firms with CEO equity holdings higher than average. Results indicate that credit rating and convertible debt reduce the effects of distress risk on equity returns, and that high ownership of the firm's equity by CEOs increases the effects of distress risk on equity returns. These results have clear implications for policymakers, investors, and managers, especially in regards equity-based compensation. In fact, Edmans and Liu (2011) highlight a potential tool to reduce risk-shifting by increasing the proportion of debt in executive compensation. The authors show

\footnotetext{
13 The Execucomp data are from 1992 to 2014. In 2006, the FAS123R changed reporting requirements. After eliminating data after 2006, primary conclusions from our tests remained unchanged. CEO equity ownership equals stock grants multiplied by stock price plus the Black-Scholes value of options.
} 
debt compensation can be both an effective means to increase liquidation values and to reduce riskshifting.

\subsection{Credit spreads and distress risk}

The risk-shifting hypothesis predicts distress risk reduces equity risk and increases debt risk. The above sections confirm a negative relationship between equity return (risk) and distress risk. In this section, we further test the risk-shifting hypothesis for bond data. Bond data, supplied by the Trade Reporting and Compliance Engine (TRACE), include FINRA over-the-counter corporate bond market real-time price information, including bond prices, yields to maturity, maturity dates, and volume. ${ }^{14}$

We construct monthly credit spreads in two steps. First, we obtain monthly yield data from the last trading observation of each month. We then use monthly treasury security data from FRED published by the Federal Reserve Bank of St. Louis as a risk-free rate. Second, we derive credit spreads equal to the difference between the yield to maturities on corporate bonds and the corresponding maturity treasury rate. ${ }^{15}$ Following Davydenko and Strebulaev (2007), we only include bonds with more than one year of remaining time to maturity. We exclude bonds issued by financial and utility firms and bonds with missing bond data. The final sample includes 509,385 monthly observations for 21,118 , and unique bonds for 1,695 unique firms.

\section{|Please insert Table 7|}

Table 7 presents the results of the Fama and MacBeth tests of corporate credit spreads. The independent variables are DR, Amt, Year, Rating, Std, ROA, and Runup. Amt is the log value of the bond face value. Year denotes the number of years to maturity. Rating denotes the credit rating of the corporate bond, following Avramov et al. (2007) transformations. Specifically, AAA takes a value of 1 and D is scored with the value 22. Thus, firms with lower credit ratings and higher credit risk correspond with

${ }^{14}$ TRACE consolidates bond prices daily data for July 1, 2002 through December 31, 2014, representing $100 \%$ of OTC activity and over $99 \%$ of total U.S. corporate bond market activity in over 30,000 securities.

${ }^{15}$ We match the corporate bond data as closely as possible to the corresponding treasury rate. For corporate bonds with a period to maturity of more than 30 years, we use the 30 -year constant maturity rate. 
higher numerical scores. Std denotes the standard deviation of prior 12-month stock returns. ROA is net income divided by total assets. Runup is the percentage change in equity prices over the past year.

Results show that the credit spreads increase $0.585 \%(t$-statistic $=10.56)$ when a firm moves into a higher default risk quintile. The $D R$ effect drops but remains significant after controlling for bond and stock characteristics, as well as proxies designed to capture effects of shareholder strategic actions. All slopes have the expected signs. $R O A$ often lacks significance, which should not be surprising because the regression also includes $D R$ and Rating. Most importantly, our tests offer further support for the riskshifting hypothesis and cast doubt on the strategic action hypothesis.

Our results provide clear evidence of negative relations of equity returns and equity risk with distress risk. Results remain strong after controlling for effects of shareholder actions and risk-shifting incentives. We show that credit spreads increase with distress risk, after controlling for various characteristics of the bond issues, as well as shareholder action effects. Credit spreads rise and equity risks fall as default probability rises, offering further support for the risk-shifting hypothesis.

\section{Conclusions}

We examine causes of the distress puzzle, aiming to reconcile the negative relation between financial distress and equity returns. In our cross-sectional regressions, we show that financial distress serves as a negative and significant predictor of future stock returns and equity risk, after controlling for stock characteristics related to firm size, book-to-market, and momentum, as well as proxies for effects of shareholder strategic actions. We find that high default risk firms tend to overinvest, destroy value, and exhaust their cash flows relative to low default risk firms. These effects are more pronounced in high growth opportunity firms and in hard-to-value firms. In support of the risk-shifting hypothesis, effects of distress risk on equity returns and risks vary significantly in the presence of different incentives or supervision mechanics. In particular, distress risk effects are higher for firms with no credit ratings or convertible debt and in firms where CEOs have above-average equity holdings.

Findings show that higher distress risk is associated with higher credit spreads, after controlling for stock and bond characteristics, as well as shareholder action proxies. Overall, our findings show that 
higher distress risk is associated with lower equity betas, lower equity returns, and higher credit spreads. The evidence offers strong support for the risk-shifting explanation for the distress risk puzzle. 


\section{Acknowledgements}

We gratefully acknowledge Dave Diltz, Larry Lockwood, Peggy Swanson, Mahmut Yasar, and participants at seminars at The University of Texas at Arlington and the Eastern Finance Association Conference for their many helpful comments. 


\section{References}

Alderson, M.J., Betker, B.L., 1996, Liquidation costs and accounting data, Financ. Manage. 25, 25-36.

Almeida, H., Campello, M., Laranjeira, B., Weisbenner, S., 2012, Corporate debt maturity and the real effects of the 2007 credit crisis, Crit. Finance Rev. 1, 3-58.

Altman, E.I., 1968. Financial ratios, discriminant analysis and prediction of corporate bankruptcy, J. Finance 23, 189-209.

Amihud, Y., 2002. Illiquidity and stock returns: cross-section and Time-series effects, J. Financ. Mark. 5, $31-56$.

Ang, A., Hodrick, R.J., Xing, Y., Zhang, X., 2006. The cross-section of volatility and expected returns, J. Finance 61, 259-299.

Avramov, D., Chordia T., 2006. Asset pricing models and financial market anomalies. Rev. Financ. Stud. $19,1001-40$.

Avramov, D., Chordia, T., Jostova, G., Philipov, A., 2007. Momentum and credit rating. J. Finance 62, 2503-2520.

Barnea, A., Haugen, R.A., Senbet, L.W., 1980. A rationale for debt maturity structure and call provisions in the agency theoretic framework. J. Finance 35, 1223-1234.

Barnea, A., Haugen, R.A. and Senbet, L.W., 1981. An equilibrium analysis of debt financing under costly tax arbitrage and agency problems. J. Finance 36, 569-581.

Berger, P., Ofek, E., and Swary, I., 1996. Investor valuation of the abandonment option. J. Financ. Econ. $42,257-287$.

Bharath, S.T., Shumway, T., 2008, Forecasting default with the Merton distance to default model, Rev. Financ. Stud. 21, 1339-1369.

Brander, J.A., Poitevin, M., 1992. Managerial compensation and the agency costs of debt finance. Manag. Decis. Econ. 13, 55-64.

Campbell, J.Y., Hilscher, J., Szilagyi, J., 2008. In search of distress risk, J. Finance 63, 2899-2939.

Carhart, M.M., 1997. On persistence in mutual fund performance, J. Finance 52, 57-82.

Chava, S., Purnanandam, A., 2010. Is default risk negatively related to stock returns?, Rev. Financ. Stud. 23, 2523-2559.

Da, Z., Guo, R.J., Jagannathan, R., 2012. CAPM for estimating the cost of equity capital: interpreting the empirical evidence, J. Financ. Econ. 103, 204-220.

Daniel, K., Grinblatt, M., Titman, S., Wermers, R., 1997. Measuring mutual fund performance with characteristic-based benchmarks, J. Finance 52, 1035-1058. 
Davydenko, S.A., Strebulaev, I.A., 2007. Strategic actions and credit spreads: an empirical investigation, J. Finance 62, 2633-2671.

Diamond, D.W., 1989, Reputational acquisition in debt markets, J. Pol. Econ. 97, 828-862.

Dichev, I.D., 1998. Is the risk of bankruptcy a systematic risk? J. Finance 53, 1131-1147.

Edmans, A., Liu Q., 2011, Inside debt, Rev. of Finance 15, 75-102.

Eisdorfer, A., 2008. Empirical evidence of risk shifting in financially distressed firms, J. Finance 63, 609637.

Ertugrul, M., Hegde, S., 2008, Board compensation practices and agency costs of debt, J. Corp. Fin. 14, 512-531.

Fama, E.F., French, K.R., 1992. The cross-section of expected stock returns, J. Finance 47, 427-465.

Fama, E.F., French, K.R., 1993. Common risk factors in the returns on stocks and bonds, J. Financ. Econ. 33, 3-56.

Fama, E.F., French, K.R., 1996. Multifactor explanations of asset pricing anomalies, J. Finance 51, 55-84.

Fama, E., French, K.R., 2015. A five-factor asset pricing model, J. Financ. Econ. 116, 1-22.

Fama, E., MacBeth, J.D., 1973. Risk, return, and equilibrium: Empirical tests, J. Pol. Econ. 81, 607-636.

Favara, G., Schroth, E., Valta, P., 2012. Strategic default and equity risk across countries, J. Finance 67, 2051-2095.

Ferguson, M.F., Shockley, R.L., 2003. Equilibrium “anomalies”, J. Finance 58, 2549-2580.

Garlappi, L., Yan, H., 2011. Financial distress and the cross-section of equity returns, J. Finance 66, 789822.

Garlappi, L., Shu, T., Yan, H., 2008. Default risk, shareholder advantage, and stock returns, Rev. Financ. Stud. 21, 2743-2778.

George, T.J., Hwang, C.Y., 2010. A resolution of the distress risk and leverage puzzles in the cross section of stock returns, J. Financ. Econ. 96, 56-79.

Gilje, E., 2016. Do firms engage in risk-shifting? Empirical evidence, Rev. Financ. Stud. 29, 2925-2954.

Green, R.C., 1984. Investment incentives, debt, and warrants, J. Financ. Econ. 13, 115-136.

Griffin, J.M., Lemmon, M.L., 2002. Book-to-market equity, distress risk and stock returns, J. Finance 57, 2317-2336.

Healy, P.M., Palepu, K.G., 2001. Information asymmetry, corporate disclosure, and the capital markets: A review of the empirical disclosure literature, J. Account. Econ. 31, 405-440. 
Hernández-Lagos, P., Povel, P., Sertsios, G., 2017, Rev. Corp. Fin. Stud. 6, 68-101.

Hirshleifer, D., Thakor, A.V., 1992, Managerial conservatism, project choice, and debt, Rev. Financ. Stud. 5, 437-470.

Jensen, M.C., Meckling, W.H., 1976. Theory of the firm: managerial behavior, agency costs and ownership structure, J. Financ. Econ. 3, 305-360.

John, T. A., John, K., 1993. Top-management compensation and capital structure, J. Finance 48, 949974.

Lewellen, J., Nagel, S., 2006. The conditional CAPM does not explain asset-pricing anomalies, J. Financ. Econ. 2, 289-314.

McLean, D., 2011. Share issuance and Cash savings, J. Financ. Econ. 99, 693-715.

Ohlson, J.A., 1980. Financial ratios and the probabilistic prediction of bankruptcy, J. Account. Res. 18, 109-131.

Ozerturk, S., 2002. Risk sharing, risk shifting and optimality of convertible debt in venture capital, Working Paper, Southern Methodist University.

Shumway, T., Warther, V.A., 1999. The delisting bias in CRSP's Nasdaq data and its implications for the size effect, J. Finance 54, 2361-2379.

Smith, C. W., Warner, J. B., 1979. On financial contracting an analysis of bond covenants, Journal of Financial Economics 7, 117-161.

Vassalou, M., Xing, Y., 2004. Default risk in equity returns, J. Finance 59, 831-868.

Wermers, R., 2004, Is money really 'smart'? New evidence on the relation between mutual fund flows, manager behavior, and performance persistence. Working Paper, University of Maryland.

Zhang, L., 2005. The value premium, J. Finance 60, 67-103. 


\section{Table 1}

\section{Summary statistics of the default probability}

This table reports the summary statistics of default probability (in percentages) presented by Campbell et al. (2008). The sample period runs from January of 1971 to December of 2014. The table reports the annual average of default probability and corresponding historical events. $N$ denotes the number of firms per year.

\begin{tabular}{|c|c|c|c|}
\hline Year & $\mathrm{N}$ & Default Probability & Historical Event (Peak) \\
\hline 1971 & 761 & 0.014 & \\
\hline 1972 & 1,348 & 0.010 & \\
\hline 1973 & 1,483 & 0.013 & Oil Crisis and Stock Market Crash \\
\hline 1974 & 1,488 & 0.009 & \\
\hline 1975 & 1,486 & 0.019 & \\
\hline 1976 & 1,414 & 0.029 & Secondary Banking Crisis of United Kingdom \\
\hline 1977 & 1,532 & 0.021 & \\
\hline 1978 & 1,491 & 0.035 & \\
\hline 1979 & 1,456 & 0.058 & The 1979 Energy Crisis and the U.S. Recession \\
\hline 1980 & 1,407 & 0.027 & \\
\hline 1981 & 1,388 & 0.049 & Latin American Debt Crisis and the U.S. Double \\
\hline 1982 & 2,090 & 0.043 & \\
\hline 1983 & 2,535 & 0.055 & \\
\hline 1984 & 2,708 & 0.119 & \\
\hline 1985 & 2,648 & 0.166 & \\
\hline 1986 & 2,666 & 0.222 & \\
\hline 1987 & 2,830 & 0.247 & \\
\hline 1988 & 2,752 & 0.435 & Black Monday 1987 \\
\hline 1989 & 2,653 & 0.558 & United Stated Saving \& Loan Crisis \\
\hline 1990 & 2,524 & 0.574 & Japanese Asset Pricing Bubble Collapsed \\
\hline 1991 & 2,557 & 0.529 & Black Wednesday \\
\hline 1992 & 2,845 & 0.530 & \\
\hline 1993 & 3,168 & 0.531 & \\
\hline 1994 & 3,516 & 0.616 & Economic Crisis in Mexico \\
\hline 1995 & 3,682 & 0.618 & \\
\hline 1996 & 3,968 & 0.627 & \\
\hline 1997 & 4,241 & 0.680 & Asian Financial Crisis \\
\hline 1998 & 4,172 & 0.829 & Russian Financial Crisis \\
\hline 1999 & 3,952 & 0.914 & \\
\hline 2000 & 3,931 & 1.005 & The early 2000 s recession \\
\hline 2001 & 3,554 & 1.801 & The U.S. dot-com Bubble Crisis \\
\hline 2002 & 3,250 & 1.311 & \\
\hline 2003 & 3,183 & 0.993 & \\
\hline 2004 & 3,184 & 0.769 & \\
\hline 2005 & 3,139 & 0.812 & \\
\hline 2006 & 3,161 & 2.608 & \\
\hline 2007 & 3,110 & 3.421 & \\
\hline 2008 & 2,972 & 6.634 & The U.S. Financial Crisis \\
\hline 2009 & 2,784 & 11.894 & \\
\hline 2010 & 2,857 & 5.678 & The European sovereign debt crisis \\
\hline 2011 & 2,686 & 3.650 & \\
\hline 2012 & 2,548 & 4.798 & \\
\hline 2013 & 2,545 & 3.706 & \\
\hline 2014 & 1,893 & 2.283 & \\
\hline
\end{tabular}




\section{Table 2}

\section{Summary statistics of firm characteristics and default probability}

This table reports summary statistics of firm characteristics and default probability. The sample period spans January 1971 - December 2014. For each month, observations are sorted by default probability into five quintiles. Panel A reports summary statistics of firm characteristics for the entire sample. Panel B reports summary statistics of firm characteristics based on the quintiles. Panel $\mathrm{C}$ reports monthly excess returns (over the 30-day Treasury bill return), risk-adjusted returns, characteristic-adjusted returns, time varying beta, and conditional beta. Risk-adjusted returns and characteristic-adjusted returns are based on $\mathrm{t}+1$ month returns. Size is natural log of market capitalization in millions. BM is the book-to-market ratio, calculated as the book value of stockholder equity at year $t-1$ divided by the market value of stockholder equity at the end of fiscal year $t-1$. These variables are matched with monthly returns from July of year $t$ to June of year $t+1 . M O M$ is stock momentum, defined as stock returns over the prior year ranging from -12 months to -2 months prior to portfolio formation. Illiquidity denotes Amihud's (2002) illiquidity measure for the past 12 months of daily trading data. Leverage denotes total liabilities over total assets.

\begin{tabular}{|c|c|c|c|c|c|}
\hline \multicolumn{6}{|c|}{ Panel A: Summary Statistics for Firm Characteristics } \\
\hline & Mean & Median & Std & Min & $\operatorname{Max}$ \\
\hline Default Probability & 1.055 & 0.002 & 9.384 & 0 & 100 \\
\hline Size & 5.009 & 4.927 & 2.033 & 0.834 & 8.586 \\
\hline BM & 0.862 & 0.659 & 0.669 & 0.072 & 2.904 \\
\hline MOM & 0.084 & 0.025 & 0.434 & -0.624 & 1.030 \\
\hline Illiquidity & 0.153 & 0.001 & 0.384 & 0 & 1.736 \\
\hline Leverage & 0.482 & 0.485 & 0.215 & 0.090 & 1.156 \\
\hline \multicolumn{6}{|c|}{ Panel B: Firm Characteristics by Default Probability Quintile } \\
\hline & $\begin{array}{c}\text { Low Quint } \\
1 \\
\end{array}$ & 2 & 3 & 4 & $\begin{array}{c}\text { High Quintile } \\
5 \\
\end{array}$ \\
\hline Default Probability & 0.000 & 0.000 & 0.002 & 0.008 & 5.264 \\
\hline Size & 5.448 & 5.788 & 5.468 & 4.715 & 3.627 \\
\hline BM & 0.616 & 0.638 & 0.805 & 1.030 & 1.219 \\
\hline MOM & 0.305 & 0.169 & 0.095 & 0.009 & -0.161 \\
\hline Illiquidity & 0.259 & 0.244 & 0.292 & 0.384 & 0.570 \\
\hline Leverage & 0.299 & 0.421 & 0.499 & 0.551 & 0.642 \\
\hline \multicolumn{6}{|c|}{ Panel C: Returns and Equity Risk by Default Probability Quintile } \\
\hline & $\begin{array}{c}\text { Low Quint } \\
1 \\
\end{array}$ & 2 & 3 & 4 & $\begin{array}{c}\text { High Quintile } \\
5 \\
\end{array}$ \\
\hline Returns (\%) & 0.948 & 0.588 & 0.573 & 0.610 & 0.303 \\
\hline Char-adjusted Returns (\%) & 0.850 & 0.533 & 0.538 & 0.676 & 0.547 \\
\hline CAPM Alpha $(\%)$ & 0.338 & 0.027 & 0.002 & 0.001 & -0.441 \\
\hline 3 -factor Alpha (\%) & 0.528 & 0.116 & -0.009 & -0.115 & -0.732 \\
\hline 4-factor Alpha (\%) & 0.318 & 0.086 & 0.129 & 0.106 & -0.241 \\
\hline 5-factor Alpha (\%) & 0.337 & 0.093 & 0.138 & 0.181 & -0.285 \\
\hline Time-varying Beta & 0.867 & 0.884 & 0.848 & 0.812 & 0.775 \\
\hline Conditional Beta & 1.203 & 1.171 & 1.153 & 1.017 & 1.003 \\
\hline
\end{tabular}




\section{Table 3}

\section{Investment, profitability, cash flow, and default probability}

This table presents the relationships between firm fundamentals and default probability. The sample period runs from 1971 to 2014. Panel A reports results based on quintiles $(D R)$ sorted by default probability. Panel B reports results based on quintiles that are first sorted by the market equity-to-book equity ratio $(M B)$ and then by default probability. Panel $\mathrm{C}$ presents the results based on quintiles that are first sorted by idiosyncratic risk $(I R)$ and then by default probability. Investment intensity equals capital expenditures divided by total assets. Profitability equals return on equity (ROE). Cash flow is the operating cash flow divided by total assets. For each year, observations are sorted into quintiles based on default probability. The table reports the time-series averages of Investment Intensity, Profitability, and Cash flow for low and high default quintiles. * denotes a $10 \%$ significance level, ${ }^{* *}$ denotes a $5 \%$ significance level, and ${ }^{* * *}$ denotes a $1 \%$ significance level.

\begin{tabular}{|c|c|c|c|}
\hline \multicolumn{4}{|c|}{ Panel A: Fundamentals by Default Probability Quintiles } \\
\hline & Low $D R$ & High $D R$ & High-Low \\
\hline Investment Intensity & 0.063 & 0.071 & $0.008^{* * *}$ \\
\hline Profitability & 0.157 & -0.174 & $-0.331^{* * *}$ \\
\hline Cash Flow & 0.276 & 0.091 & $-0.185^{* * *}$ \\
\hline \multicolumn{4}{|c|}{ Panel B: Fundamentals Double Sorted by Default Probability and $M B$ Quintiles } \\
\hline & Low $D R$ & High $D R$ & High-Low \\
\hline \multicolumn{4}{|l|}{ Investment Intensity } \\
\hline Low $M B$ & 0.053 & 0.053 & 0.000 \\
\hline High $M B$ & 0.081 & 0.081 & 0.000 \\
\hline Difference & $0.028^{* * *}$ & $0.028^{* * *}$ & \\
\hline \multicolumn{4}{|l|}{ Profitability } \\
\hline Low $M B$ & 0.083 & -0.114 & $-0.197^{* * *}$ \\
\hline High $M B$ & 0.194 & -0.472 & $-0.666^{* * *}$ \\
\hline Difference & $0.111^{* * *}$ & $-0.358^{* * *}$ & \\
\hline \multicolumn{4}{|l|}{ Cash Flow } \\
\hline Low $M B$ & 0.210 & 0.064 & $-0.146^{* * *}$ \\
\hline High $M B$ & 0.322 & 0.136 & $-0.186^{* * *}$ \\
\hline Difference & $0.112^{* * *}$ & $0.072^{* * *}$ & \\
\hline \multicolumn{4}{|c|}{ Panel C: Fundamentals Double Sorted by Default Probability and IR Quintiles } \\
\hline & Low $D R$ & High $D R$ & High-Low \\
\hline \multicolumn{4}{|l|}{ Investment Intensity } \\
\hline Low $I R$ & 0.051 & 0.061 & $0.010^{* * *}$ \\
\hline High $I R$ & 0.052 & 0.069 & $0.017^{* * *}$ \\
\hline Difference & $0.001^{* * *}$ & $0.008^{* * *}$ & \\
\hline \multicolumn{4}{|l|}{ Profitability } \\
\hline Low $I R$ & 0.166 & 0.066 & $-0.160^{* * *}$ \\
\hline High $I R$ & 0.069 & -0.435 & $-0.504^{* * *}$ \\
\hline Difference & $-0.097^{* * *}$ & $-0.501^{* * * *}$ & \\
\hline \multicolumn{4}{|l|}{ Cash Flow } \\
\hline Low $I R$ & 0.208 & 0.057 & $-0.152^{* * * *}$ \\
\hline High $I R$ & 0.307 & 0.087 & $-0.220^{* * *}$ \\
\hline Difference & $0.099^{* * *}$ & $0.030^{* * *}$ & \\
\hline
\end{tabular}




\section{Table 4}

\section{Fama-MacBeth regressions for equity returns and equity risks}

This table represents the Fama-MacBeth regression of equity risk on distress risk. The dependent variable is either equity returns or equity risk. Equity returns are one-month holding period returns minus the risk-free rate, and equity risk is the time-varying beta. The independent variables are DR, Cash Flow, Cash, Sales Growth, R\&D, DY, TANGIBILITY, MBTA, and CURRENT. DR is the quintile of default probability. Size is the log value of market capitalization (in millions). BM denotes book-to-market ratios. MOM denotes prior year returns ranging from -12 months to -2 months. Cash Flow is the operating cash flow divided by total assets. Cash is the cash and short-term investment divided by total assets. Sales Growth is the average annual percent change in sales over the last three years. $R \& D$ denotes research and development costs divided by total assets. $D Y$ is the annual dividend per share divided by the price per share at the end of the month. MBTA is the sum of market value of equity and book value of debt divided by book value of total assets. TANGIBILITY is defined as 1 minus property, plant and equipment divided by total assets. CURRENT is the ratio of current liabilities divided by total liabilities. $t$-statistics are reported in parentheses. ${ }^{*}$ denotes a $10 \%$ significance level, ${ }^{* *}$ denotes a $5 \%$ significance level, and ${ }^{* * *}$ denotes a $1 \%$ significance level.

\begin{tabular}{|c|c|c|c|c|c|c|c|c|c|c|}
\hline \multicolumn{11}{|c|}{ Panel A: Equity Returns } \\
\hline Constant & DR & Size & $\mathrm{BM}$ & MOM & & & TANGIBILITY & MBTA & CURRENT & Average $\mathrm{R}^{2}$ \\
\hline $\begin{array}{l}1.435^{* * *} \\
(6.02)\end{array}$ & $\begin{array}{l}-0.184^{* * *} \\
(-3.66)\end{array}$ & & & & & & & & & $1.10 \%$ \\
\hline $\begin{array}{l}1.584^{\text {**** }} \\
(4.93)\end{array}$ & $\begin{array}{l}-0.203^{* * *} \\
(-5.97)\end{array}$ & $\begin{array}{l}-0.091 * * \\
(-2.42)\end{array}$ & $\begin{array}{l}0.244^{* * *} \\
(3.99)\end{array}$ & $\begin{array}{l}0.607^{\text {**** }} \\
(3.65)\end{array}$ & & & & & & $3.05 \%$ \\
\hline $\begin{array}{l}1.128^{\text {**** }} \\
(4.16)\end{array}$ & $\begin{array}{l}-0.171^{* * *} \\
(-4.91)\end{array}$ & $\begin{array}{l}-0.080 * * \\
(-2.21)\end{array}$ & $\begin{array}{l}0.233^{* * *} \\
(4.18)\end{array}$ & $\begin{array}{l}0.620^{* * * *} \\
(3.63)\end{array}$ & & & $\begin{array}{l}0.424^{*} \\
(1.90)\end{array}$ & & & $3.54 \%$ \\
\hline $\begin{array}{l}1.607^{\text {*** }} \\
(5.15)\end{array}$ & $\begin{array}{l}-0.205^{\text {**** }} \\
(-6.02)\end{array}$ & $\begin{array}{l}-0.090 * * \\
(-2.36)\end{array}$ & $\begin{array}{l}0.239^{* * *} \\
(4.18)\end{array}$ & $\begin{array}{l}0.596^{* * * *} \\
(3.63)\end{array}$ & & & & $\begin{array}{l}-0.007 \\
(-0.30)\end{array}$ & & $3.21 \%$ \\
\hline $\begin{array}{l}1.489^{\text {**** }} \\
(5.25)\end{array}$ & $\begin{array}{l}-0.186^{\text {**** }} \\
(-4.89)\end{array}$ & $\begin{array}{l}-0.091 * * \\
(-2.53)\end{array}$ & $\begin{array}{l}0.235^{* * *} \\
(3.97)\end{array}$ & $\begin{array}{l}0.606^{\text {*** }} \\
(3.69)\end{array}$ & & & & & $\begin{array}{l}0.059 \\
(0.37)\end{array}$ & $3.39 \%$ \\
\hline $\begin{array}{l}1.256^{* * *} \\
(4.53)\end{array}$ & $\begin{array}{l}-0.181^{\text {**** }} \\
(-4.81)\end{array}$ & $\begin{array}{l}-0.084 * * \\
(-2.35)\end{array}$ & $\begin{array}{l}0.227^{* * * *} \\
(4.13)\end{array}$ & $\begin{array}{l}0.593^{* * * *} \\
(3.73)\end{array}$ & & & $\begin{array}{l}0.449^{* *} \\
(2.25)\end{array}$ & $\begin{array}{l}-0.012 \\
(-0.51)\end{array}$ & $\begin{array}{l}-0.104 \\
(-0.80)\end{array}$ & $3.87 \%$ \\
\hline \multicolumn{11}{|c|}{ Panel B: Equity Risk } \\
\hline Constant & DR & $\begin{array}{l}\text { Cash } \\
\text { Flow }\end{array}$ & Cash & $\begin{array}{l}\text { Sales } \\
\text { Growth }\end{array}$ & $\mathrm{R} \& \mathrm{D}$ & DY & TANGIBILITY & MBTA & CURRENT & Average $\mathrm{R}^{2}$ \\
\hline $\begin{array}{l}0.974^{* * * *} \\
(43.21)\end{array}$ & $\begin{array}{l}-0.054^{* * *} \\
(-9.08)\end{array}$ & & & & & & & & & $3.56 \%$ \\
\hline $\begin{array}{l}0.923^{\text {**** }} \\
(31.73)\end{array}$ & $\begin{array}{l}-0.037^{\text {**** }} \\
(-6.22)\end{array}$ & $\begin{array}{l}-0.138^{* * *} \\
(-4.83)\end{array}$ & $\begin{array}{l}0.164^{* * *} \\
(3.43)\end{array}$ & $\begin{array}{l}0.121^{\text {*** }} \\
(3.66)\end{array}$ & $\begin{array}{l}1.402^{* * * *} \\
(5.38)\end{array}$ & $\begin{array}{l}-0.004 \\
(-1.55)\end{array}$ & & & & $8.16 \%$ \\
\hline $\begin{array}{l}0.815^{* * * *} \\
(21.07)\end{array}$ & $\begin{array}{l}-0.034^{* * * *} \\
(-5.52)\end{array}$ & $\begin{array}{l}-0.082^{* * * *} \\
(-3.58)\end{array}$ & $\begin{array}{l}0.075^{*} \\
(1.73)\end{array}$ & $\begin{array}{l}0.119^{\text {*** }} \\
(3.75)\end{array}$ & $\begin{array}{l}1.319^{* * *} \\
(5.39)\end{array}$ & $\begin{array}{l}-0.003 \\
(-0.13)\end{array}$ & $\begin{array}{l}0.142^{* * *} \\
(4.02)\end{array}$ & & & $9.36 \%$ \\
\hline $\begin{array}{l}0.791^{* * * *} \\
(23.53)\end{array}$ & $\begin{array}{l}-0.023^{* * * *} \\
(-3.53)\end{array}$ & $\begin{array}{l}-0.130^{* * *} \\
(-4.90)\end{array}$ & $\begin{array}{l}0.101 * * \\
(2.15)\end{array}$ & $\begin{array}{l}0.111^{\text {**** }} \\
(3.48)\end{array}$ & $\begin{array}{l}1.196^{* * *} \\
(5.00)\end{array}$ & $\begin{array}{l}-0.003 \\
(-1.27)\end{array}$ & & $\begin{array}{l}0.079^{\text {**** }} \\
(6.47)\end{array}$ & & $9.50 \%$ \\
\hline $\begin{array}{l}0.955^{\text {**** }} \\
(26.55)\end{array}$ & $\begin{array}{l}-0.039^{\text {**** }} \\
(-6.21)\end{array}$ & $\begin{array}{l}-0.138^{* * * *} \\
(-4.77)\end{array}$ & $\begin{array}{l}0.198^{* * *} \\
(4.80)\end{array}$ & $\begin{array}{l}0.120^{* * * *} \\
(3.62)\end{array}$ & $\begin{array}{l}1.435^{* * *} \\
(5.43)\end{array}$ & $\begin{array}{l}-0.004 \\
(-1.43)\end{array}$ & & & $\begin{array}{l}-0.064^{* * *} \\
(-3.14)\end{array}$ & $8.81 \%$ \\
\hline $\begin{array}{l}0.705^{* * * *} \\
(15.04)\end{array}$ & $\begin{array}{l}-0.025^{\text {**** }} \\
(-3.64)\end{array}$ & $\begin{array}{l}-0.049 * * \\
(-2.36)\end{array}$ & $\begin{array}{l}0.048 \\
(1.21)\end{array}$ & $\begin{array}{l}0.099^{* * *} \\
(3.71)\end{array}$ & $\begin{array}{l}1.129^{* * *} \\
(5.10)\end{array}$ & $\begin{array}{l}0.000 \\
(0.15)\end{array}$ & $\begin{array}{l}0.236^{* * *} \\
(5.32)\end{array}$ & $\begin{array}{l}0.088^{* * * *} \\
(7.33)\end{array}$ & $\begin{array}{l}-0.177^{\text {**** }} \\
(-8.24)\end{array}$ & $11.66 \%$ \\
\hline
\end{tabular}




\section{Table 5}

\section{Trends in equity risk sensitivities}

This table reports trends in the equity risk sensitivities of the highest distress risk portfolio $(D R=5)$. The equity risk sensitivities are the coefficients from monthly cross-sectional regressions of equity risk on cash flow variables:

$$
\text { Beta }_{i, t}=\alpha+\beta_{1} \text { Cash Flow }_{i, t}+\beta_{2}^{\prime} \text { Controls }_{i, t}+\varepsilon_{i, t}
$$

Controls include Cash, Sales Growth, $R \& D$, and $D Y$. The Cash Flow and Control variables are defined in Table 4. $t$-statistics are reported in parentheses. ${ }^{*}$ denotes a $10 \%$ significance level, ${ }^{* *}$ denotes a $5 \%$ significance level, and ${ }^{* * * *}$ denotes a $1 \%$ significance level. Durbin-Watson statistics are reported at the bottom of each panel.

\begin{tabular}{lll}
\hline & $\begin{array}{l}\text { Time-varying } \\
\text { Beta }\end{array}$ & \multicolumn{1}{c}{$\begin{array}{c}\text { Conditional } \\
\text { Beta }\end{array}$} \\
\hline Constant & $-0.048^{* * *}$ & $-0.102^{* * *}$ \\
& $(-3.96)$ & $(-4.45)$ \\
Trend & $1.03 \mathrm{e}-03^{* * *}$ & $2.26 \mathrm{e}-03^{* *}$ \\
& $(3.29)$ & $(3.83)$ \\
Lag 1 & $0.740^{* * *}$ & $0.709^{* * *}$ \\
& $(16.73)$ & $(16.00)$ \\
Lag 2 & 0.039 & $0.106^{*}$ \\
& $(0.71)$ & $(0.94)$ \\
Lag 3 & -0.008 & -0.009 \\
& $(-0.15)$ & $(-0.17)$ \\
Lag 4 & $0.083^{*}$ & 0.036 \\
& $(1.89)$ & $(0.80)$ \\
Months & 515 & 515 \\
Durbin-Watson & 1.943 & 2.000 \\
\hline
\end{tabular}




\section{Table 6}

Distress effects for subsamples according to credit agency coverage, existence of convertible debt, and CEO equity ownership

This table presents coefficients for the full model in Table 3, with an interaction variable. For each month, the sample is divided into two subsamples based on specific criteria. These criteria include whether a firm is followed by a credit agency (Panel A, $C R=1$ if the firm's debt has a credit rating), whether a firm has convertible bonds (Panel B, $C B=1$ if the firm issues convertible bonds), and whether a firm's CEO has equity holdings above the sample median (Panel C, $C E O=1$ if CEO holdings are above the sample median). $D R$ is the default risk quintile. $t$-statistics are reported in parentheses. ${ }^{*}$ denotes a $10 \%$ significance level, ${ }^{* *}$ denotes a $5 \%$ significance level, and ${ }^{* * *}$ denotes a $1 \%$ significance level.

\begin{tabular}{|c|c|c|}
\hline \multicolumn{3}{|c|}{ Panel A: Credit Agency Coverage } \\
\hline & DR & DR.CR \\
\hline Equity Return & $\begin{array}{l}-0.241^{* * * *} \\
(-6.76)\end{array}$ & $\begin{array}{l}0.007^{* * *} \\
(2.36)\end{array}$ \\
\hline Equity Risk & $\begin{array}{l}-0.046^{* * * *} \\
(-7.33) \\
\end{array}$ & $\begin{array}{l}0.070^{* * * *} \\
(4.46)\end{array}$ \\
\hline \multicolumn{3}{|c|}{ Panel B: Convertible Bonds } \\
\hline & DR & $\mathrm{DR} \cdot \mathrm{CB}$ \\
\hline Equity Return & $\begin{array}{l}-0.211^{* * * *} \\
(-6.40)\end{array}$ & $\begin{array}{l}0.017^{* *} \\
(2.10)\end{array}$ \\
\hline Equity Risk & $\begin{array}{l}-0.062^{* * * *} \\
(-8.66) \\
\end{array}$ & $\begin{array}{c}0.060^{* * *} \\
(13.02)\end{array}$ \\
\hline \multicolumn{3}{|c|}{ Panel B: CEO } \\
\hline & DR & $\mathrm{DR} \cdot \mathrm{CEO}$ \\
\hline Equity Return & $\begin{array}{l}-0.262^{* * * *} \\
(-5.90)\end{array}$ & $\begin{array}{l}-0.053^{* * *} \\
(-2.62)\end{array}$ \\
\hline Equity Risk & $\begin{array}{l}-0.015^{* *} \\
(-2.09)\end{array}$ & $\begin{array}{l}-0.023^{\text {*** }} \\
(-4.82)\end{array}$ \\
\hline
\end{tabular}




\section{Table 7}

\section{Bond risk and distress risk}

This table presents results of Fama-MacBeth regressions of bond risk on distress risk. The dependent variable is the yield spread between the company bond yields and corresponding maturity treasury yields. The independent variables are DR, Amt, Year, Rating, Std, ROA, Runup, MBTA, TANGIBILITY, and CURRENT. DR is the quintile of the default probability. Amt is the log value of the bond face value. Year is the number of years until maturity. Rating denotes the credit rating of the corporate bond. A high numerical score corresponds with a lower credit rating. Std is the standard deviation of the prior 12-month stock return. ROA is the net income over total assets for the firm. Runup is the percentage change in equity prices over the past year. $t$-statistics are reported in parentheses. ${ }^{*}$ denotes a $10 \%$ significance level, ${ }^{* *}$ denotes a $5 \%$ significance level, and ${ }^{* * *}$ denotes a $1 \%$ significance level.

\begin{tabular}{|c|c|c|c|c|c|c|c|c|c|c|c|}
\hline Constant & DR & Amt & Year & Rating & Std & $\mathrm{ROA}$ & Runup & MBTA & TANGIBILITY & CURRENT & Average $\mathrm{R}^{2}$ \\
\hline $\begin{array}{l}0.540^{* * *} \\
(4.55)\end{array}$ & $\begin{array}{l}0.585^{\text {**** }} \\
(10.56)\end{array}$ & & & & & & & & & & $4.39 \%$ \\
\hline $\begin{array}{l}-0.829^{* * *} \\
(-4.96)\end{array}$ & $\begin{array}{l}0.366^{* * *} \\
(10.82)\end{array}$ & $\begin{array}{l}-0.011 \\
(-1.09)\end{array}$ & $\begin{array}{l}0.015^{\text {**** }} \\
(2.69)\end{array}$ & $\begin{array}{l}0.228^{* * *} \\
(22.70)\end{array}$ & & & & & & & $14.95 \%$ \\
\hline $\begin{array}{l}-0.893^{\text {**** }} \\
(-3.67)\end{array}$ & $\begin{array}{l}0.253^{\text {**** }} \\
(6.44)\end{array}$ & $\begin{array}{l}-0.058^{* * *} \\
(-6.24)\end{array}$ & $\begin{array}{l}0.031^{\text {**** }} \\
(4.56)\end{array}$ & $\begin{array}{l}0.153^{* * *} \\
(9.09)\end{array}$ & $\begin{array}{l}76.046^{* * *} \\
(9.21)\end{array}$ & $\begin{array}{l}-1.222 * \\
(-1.69)\end{array}$ & $\begin{array}{l}-0.205^{* *} \\
(-2.18)\end{array}$ & & & & $24.80 \%$ \\
\hline $\begin{array}{l}-1.118^{\text {**** }} \\
(-3.70)\end{array}$ & $\begin{array}{l}0.286^{\text {*** }} \\
(6.76)\end{array}$ & $\begin{array}{l}-0.060^{* * *} \\
(-6.25)\end{array}$ & $\begin{array}{l}0.031^{\text {**** }} \\
(4.60)\end{array}$ & $\begin{array}{l}0.155^{\text {*** }} \\
(8.54)\end{array}$ & $\begin{array}{l}75.006^{* * * *} \\
(8.85)\end{array}$ & $\begin{array}{l}-1.358^{*} \\
(-1.82)\end{array}$ & $\begin{array}{l}-0.151^{* * *} \\
(-1.97)\end{array}$ & $\begin{array}{l}0.151^{\text {*** }} \\
(3.70)\end{array}$ & & & $25.05 \%$ \\
\hline $\begin{array}{l}-1.140^{\text {**** }} \\
(-4.28)\end{array}$ & $\begin{array}{l}0.263^{\text {*** }} \\
(6.56)\end{array}$ & $\begin{array}{l}-0.060^{* * *} \\
(-6.30)\end{array}$ & $\begin{array}{l}0.032^{* * * *} \\
(4.63)\end{array}$ & $\begin{array}{l}0.154^{* * *} \\
(9.26)\end{array}$ & $\begin{array}{l}77.579^{* * * *} \\
(9.23)\end{array}$ & $\begin{array}{l}-1.070 \\
(-1.51)\end{array}$ & $\begin{array}{l}-0.148 \\
(-1.53)\end{array}$ & & $\begin{array}{l}0.245^{* * *} \\
(2.66)\end{array}$ & & $25.15 \%$ \\
\hline $\begin{array}{l}-0.831^{* * *} \\
(3.02)\end{array}$ & $\begin{array}{l}0.258^{* * *} \\
(5.52)\end{array}$ & $\begin{array}{l}-0.061^{* * *} \\
(-6.14)\end{array}$ & $\begin{array}{l}0.032^{* * * *} \\
(4.56)\end{array}$ & $\begin{array}{l}0.152^{\text {*** }} \\
(6.79)\end{array}$ & $\begin{array}{l}74.789^{* * *} \\
(8.69)\end{array}$ & $\begin{array}{l}-1.340^{*} \\
(-1.81)\end{array}$ & $\begin{array}{l}-0.205^{* *} \\
(-2.16)\end{array}$ & & & $\begin{array}{l}-0.017 \\
(-0.11)\end{array}$ & $25.15 \%$ \\
\hline $\begin{array}{l}-1.050^{\text {**** }} \\
(-4.18)\end{array}$ & $\begin{array}{l}0.298^{\text {**** }} \\
(5.54)\end{array}$ & $\begin{array}{l}-0.067^{* * *} \\
(-5.43)\end{array}$ & $\begin{array}{l}0.034^{* * * *} \\
(4.80)\end{array}$ & $\begin{array}{l}0.164^{\text {**** }} \\
(5.51)\end{array}$ & $\begin{array}{l}71.688^{* * * *} \\
(7.40)\end{array}$ & $\begin{array}{l}-1.113 \\
(-1.45)\end{array}$ & $\begin{array}{l}-0.241^{* * *} \\
(-2.29)\end{array}$ & $\begin{array}{l}0.082^{*} \\
(1.91)\end{array}$ & $\begin{array}{l}0.072 \\
(0.38)\end{array}$ & $\begin{array}{l}0.001 \\
(0.01)\end{array}$ & $25.73 \%$ \\
\hline
\end{tabular}




\section{Figure 1}

Investment intensity, ROE, and Cash Flow and over time

This figure presents the 5-year moving averages of Investment Intensity, Cash Flow, and ROE for the low and high default portfolios for the overall period.
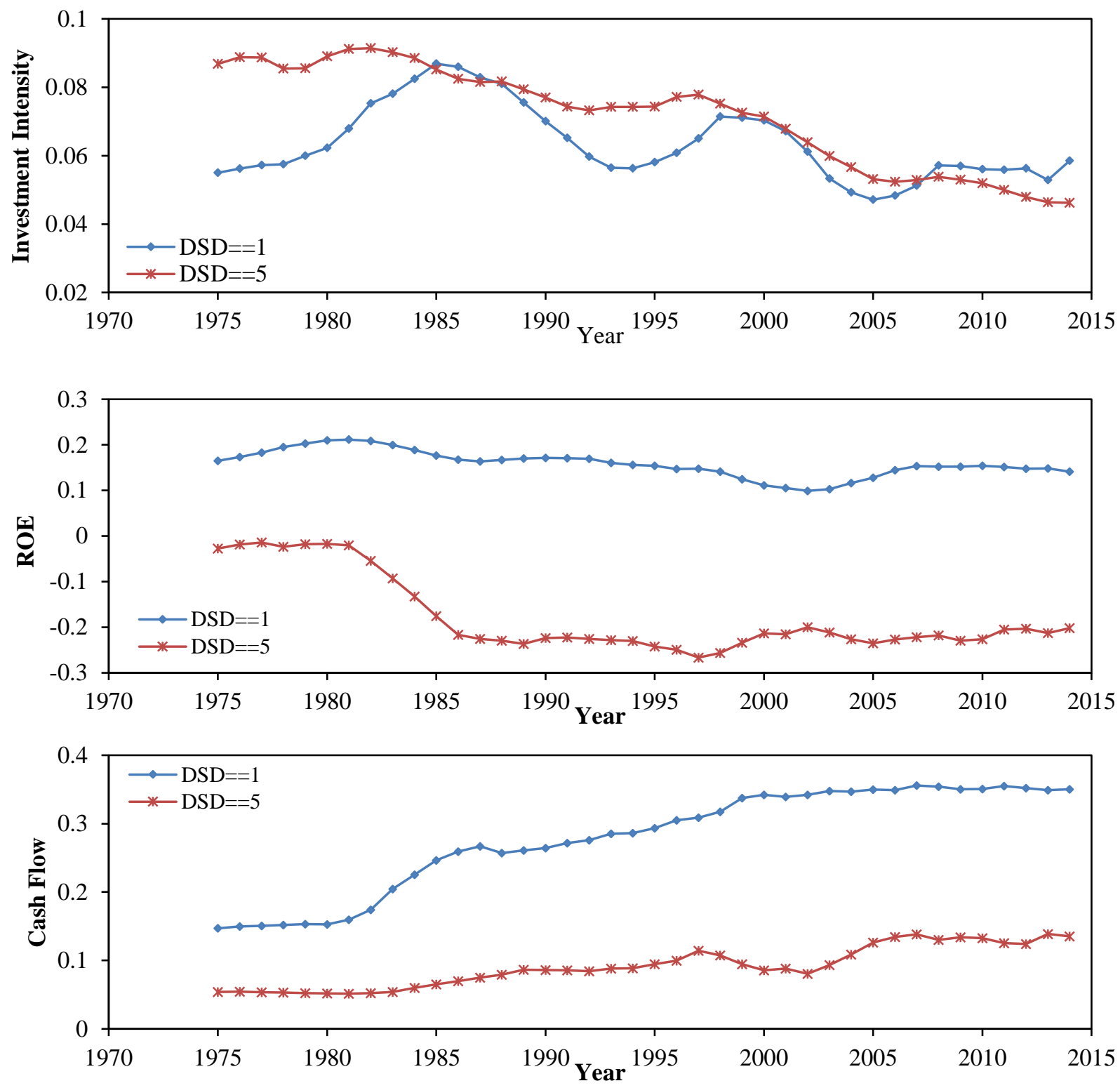


\section{Figure 2}

\section{Cumulative abnormal returns for each default portfolio}

This figure plots the average cumulative abnormal returns of each default portfolio $(1=$ low default portfolio, 5 = high default portfolio). For every month, firms are sorted into five groups based on default probability levels. Cumulative abnormal returns are tracked over 12 months. Numbers in the figure denote values that are first value-weighted within each portfolio and that are then averaged over the sample period. The time period ranges from January 1971 through December 2014. Abnormal returns are calculated relative to the Fama-French-Carhart 4 factors. Loadings are estimated from the prior 5-year monthly returns with a minimum of 36 months. Abnormal returns are then accumulated over the 12-month post-formation period.

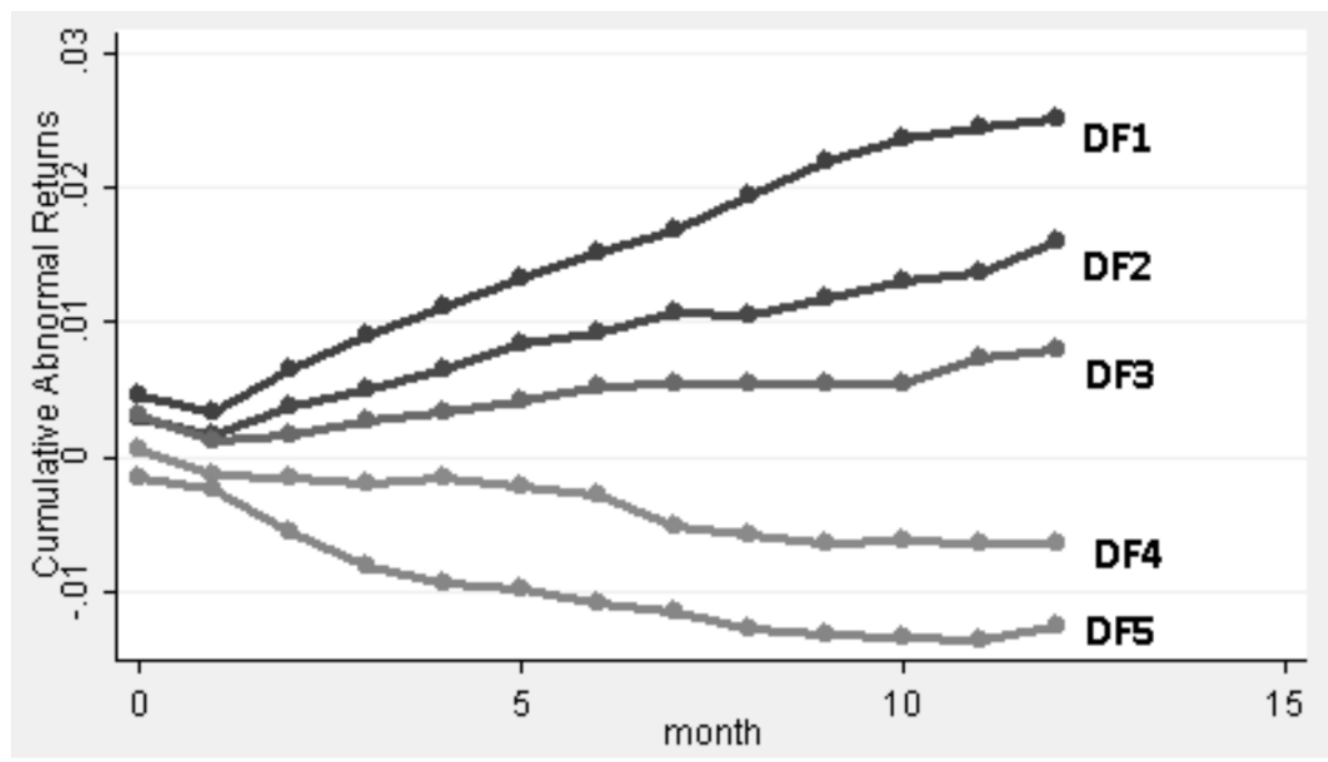

